\title{
Commentary on Paracrine GABA and insulin regulate pancreatic alpha cell proliferation in a mouse model of type 1 diabetes
}

\author{
Wei-Yang $\mathrm{Lu}^{1,2 *}$ \\ ${ }^{1}$ Department of Physiology and Pharmacology, University of Western Ontario, Canada \\ ${ }^{2}$ Robarts Research Institute, University of Western Ontario, Canada
}

\begin{abstract}
A significant increase in pancreatic $\alpha$-cells is observed in patients and animal models with recent-onset type 1 diabetes (T1D). Our recent studies suggest that the increase in $\alpha$-cell proliferation in recent-onset T1D results, at least partially, from a decline of the paracrine factor $\gamma$-aminobutyric acid as a consequence of $\beta$-cell deficiency.
\end{abstract}

Five ( $\alpha-, \beta-, \delta, \mathrm{PP}-$, and $\varepsilon$ ) subtypes of endocrine cells are located closely within the pancreatic islets of Langerhans and they are responsible for the production and release of specific hormones that regulate glucose levels. Among these endocrine cells, $\alpha$ - and $\beta$-cells are mostly studied as they operate cooperatively under physiological conditions, secreting the 'counter-regulatory' hormones glucagon and insulin respectively thus ensuring normoglycaemia. Autoimmune destruction of the $\beta$-cells results in type 1 diabetes mellitus (T1D) because of a significant decline of insulin production. Intriguingly, in patients [1] and animal models [2] with recent-onset T1D, a significant increase in $\alpha$-cells ( $\alpha$-cell hyperplasia) appears within pancreatic islets. However, treating T1D mice with insulin neither protects against $\beta$-cell loss nor inhibits $\alpha$-cell proliferation [3]. The mechanisms underlying a-cell hyperplasia in recent-onset T1D has long been unclear.

Gamma-aminobutyric acid (GABA), a well-known inhibitory neurotransmitter is widely utilised as a signalling molecule by cells outside the central nervous system, including pancreatic $\beta$-cells [4-6], immune cells [7] and epithelial cells in the intestine [8], the lung [9$11]$ and the liver $[12,13]$. Unlike neurons, pancreatic $\beta$-cells produce GABA mainly through a pathway referred to as the GABA shunt [14], a closed-loop metabolic process occurring in mitochondria with the dual purpose of producing and conserving the supply of GABA. The GABA shunt starts with the transamination of $\alpha$-ketoglutarate formed from glucose metabolism via the tricarboxylic acid cycle, by GABA/ a-oxoglutarate transaminase, into L-glutamic acid. The latter is then catalyzed into GABA by decarboxylation via the enzymatic activity of glutamic acid decarboxylase (GAD). Early studies showed that the $\beta$-cells express GAD and produce GABA. In addition, type A GABA receptors $\left(\mathrm{GABA}_{\mathrm{A}} \mathrm{Rs}\right)$, a class of ligand gated chloride channels, are expressed in both $\beta$ - and $\alpha$-cells $[4,15,16]$. Because of the disparity in expression levels of $\mathrm{Cl}^{-}$-intruding and chloride-extruding transporters, the intracellular $\mathrm{Cl}^{-}$concentration is high in $\beta$-cells but low in $\beta$-cells $[17,18]$. As a result, stimulation of $\mathrm{GABA}_{\mathrm{A}} \mathrm{Rs}$ in the $\beta$-cells causes $\mathrm{Cl}^{-}$ efflux and membrane depolarisation, increasing $\mathrm{Ca}^{2+}$ entry and insulin secretion $[4,15,19]$, whereas activation of $\mathrm{GABA}_{\mathrm{A}}$ Rs in $\alpha$-cells results in
$\mathrm{Cl}^{-}$influx and membrane hyperpolarisation, decreasing $\mathrm{Ca}^{2+}$ entry and glucagon release $[16,20]$.

We recently explored whether GABA, as a paracrine factor, regulates $\alpha$-cell proliferation using a mouse model with streptozotocin (STZ)-induced T1D [21]. We demonstrated that intraperitoneal STZ causes a rapid decline of GAD and insulin in $\beta$-cells, which is followed by elevated mTOR activity in $\alpha$-cells (glucagon ${ }^{+}$) 1 day after STZ and increased $\mathrm{Ki} 67^{+} /$glucagon ${ }^{+}$cells 2 days after STZ. By two weeks after STZ, a significantly increased $\alpha$-cell mass appears in pancreatic islets, in which the $\mathrm{GAD}^{+} /$insulin $^{+}$cells decreases while the ALDH1a3 ${ }^{+} /$ insulin $^{+}$cells increases. Cells expressing high levels of ALDH1a3 display progenitor/stem cell-like features. Excitingly, treating the STZinjected mice with GABA not only significantly reduces $\mathrm{ALDH}_{1 \mathrm{a}}{ }^{+}$/ insulin ${ }^{+}$cells and increases the $\mathrm{GAD}^{+} /$insulin $^{+}$cells, but also prevents a-cell hyperplasia and hyperglucagonaemia. These findings suggest that in normal pancreatic islets, the autocrine GABA protects $\beta$-cell from injuries and/or phenotypic dedifferentiation while the paracrine GABA inhibits $\alpha$-cell proliferation. Whereas, in early-onset T1D the increased $\alpha$-cell proliferation might be initiated by a decline in the paracrine factor GABA and/or insulin, as a result of $\beta$-cell loss.

To explore whether the paracrine factor GABA or insulin restrains $a$-cell proliferation, we tested the effect of the selective $G_{A B A} R$ agonist muscimol and insulin, respectively, on proliferation of aTC1-6 cells, a widely used mouse pancreatic a-cell line. Our assays showed that muscimol alone has no effect on $\alpha \mathrm{TC} 1-6$ cell proliferation while insulin significantly increases aTC1-6 proliferation as previously reported

${ }^{\star}$ Correspondence to: Wei-Yang Lu, Department of Physiology and Pharmacology, University of Western Ontario, Robarts Research Institute, University of Western Ontario; 1151 Richmond St. N, London, ON, N6A 5B7, Canada, Tel: 519-9315777 ex 24282; E-mail: wlu53@uwo.ca

Key words: $\gamma$-aminobutyric acid, paracrine factor, $\alpha$-cell hyperplasia

Received: May 12, 2018; Accepted: May 28, 2018; Published: May 31, 2018 
[22]. Remarkably, muscimol effectively prevents aTC1-6 proliferation in the presence of insulin. Given that insulin increases GABA Rs on the surface of $\alpha \mathrm{TC} 1-6$ cells [16], we propose that under physiological conditions, insulin maintains GABA Rs on $\alpha$-cells, where GABA, via $\mathrm{GABA}_{\mathrm{A}} \mathrm{Rs}$, retains $\alpha$-cell proliferation.

How does the paracrine GABA signalling restrain $\alpha$-cell proliferation? The $\mathrm{Ca}^{2+}$-dependent activity of mTOR upregulates the proliferation and renewal of pancreatic endocrine cells [22,23]. Activation of GABA Rs hyperpolarises $a$-cells [16] hence decreases voltage-gated $\mathrm{Ca}^{2+}$ channel activity. Indeed, our $\mathrm{Ca}^{2+}$-imaging analyses show that GABA significantly lowered cytosolic $\mathrm{Ca}^{2+}$ of $\alpha \mathrm{TC} 1-6$ cell. In addition, our immunoblotting assays showed that insulin increases the levels of p-mTOR and its downstream kinase p-P70S6K in aTC1-6 cells, whereas these effect of insulin are blocked by muscimol. Together, these data suggest that activating GABA $\mathrm{Rs}$ reduces $\mathrm{Ca}^{2+}$ entry and lowers mTOR activity in $\alpha$-cells hence inhibiting their proliferation.

On the basis of available data, we propose that in normal pancreatic islets, insulin signalling maintains a stable expression of GABA Rs on the surface of $\alpha$-cells, whereas GABA, through GABA ${ }_{A}$ Rs, keeps these cells hyperpolarised hence restraining their cytosolic $\mathrm{Ca}^{2+}$, mTOR activity and proliferation. Under conditions of T1D, however, severe $\beta$-cell loss and/or $\beta$-cell "dedifferentiation" result in a decline in intraislet insulin and GABA causing $\alpha$-cell hyperplasia. Administration of GABA to rodents with STZ-induced diabetes facilitates $\beta$-cell generation [15] and prevents $\alpha$-cell proliferation [21] hence improving glucose tolerance. Severe $\beta$-cell injury/loss induces $\alpha$-to- $\beta$ cell transdifferentiation [24]. In this regard, a recent study demonstrated that long-term stimulation of $\mathrm{GABA}_{\mathrm{A}}$ Rs facilitates $\alpha$-to- $\beta$ cell transdifferentiation in normal mice by regulating Pax4 expression [25]. The issue as to whether GABA inhibits $\alpha$-proliferation but enhances $\alpha$-to- $\beta$ cell transdifferentiation in T1D conditions remains to be addressed by future studies.

\section{References}

1. Willcox A, Richardson SJ, Bone AJ, Foulis AK, Morgan NG (2010) Evidence of increased islet cell proliferation in patients with recent-onset type 1 diabetes. Diabetologia 53: 2020-2028. [Crossref]

2. Li Z, Karlsson FA, Sandler S (2000) Islet loss and alpha cell expansion in type 1 diabetes induced by multiple low-dose streptozotocin administration in mice. $J$ Endocrinol 165: 93-99. [Crossref]

3. Meier JJ, Ueberberg S, Korbas S, Schneider S (2011) Diminished glucagon suppression after beta-cell reduction is due to impaired alpha-cell function rather than an expansion of alpha-cell mass. Am J Physiol Endocrinol Metab 300: E717-723. [Crossref]

4. Dong H, Kumar M, Zhang Y, Gyulkhandanyan A, Xiang YY, et al. (2006) Gammaaminobutyric acid up- and downregulates insulin secretion from beta cells in concert with changes in glucose concentration. Diabetologia 49: 697-705. [Crossref]

5. Feng MM, Xiang YY, Wang S, Lu WY (2013) An autocrine $\hat{I}^{3}$-aminobutyric acid signaling system exists in pancreatic $\hat{\mathrm{I}}^{2}$-cell progenitors of fetal and postnatal mice. Int J Physiol Pathophysiol Pharmacol 5: 91-101. [Crossref]

6. Wang S, Luo Y, Feng A, Li T, Yang X, et al. (2014) Ethanol induced impairment of glucose metabolism involves alterations of GABAergic signaling in pancreatic $\hat{\mathrm{I}}^{2}$ cells. Toxicology 326: 44-52. [Crossref]
7. Tian J, Dang H, Chen Z, Guan A, Jin Y, et al. (2013) $\hat{\mathrm{I}}^{3}$-Aminobutyric acid regulates both the survival and replication of human $\hat{I}^{2}$-cells. Diabetes 62: 3760-3765. [Crossref]

8. Li Y, Xiang YY, Lu WY, Liu C, Li J (2012) A novel role of intestine epithelial GABAergic signaling in regulating intestinal fluid secretion. Am J Physiol Gastrointest Liver Physiol 303: G453-460. [Crossref]

9. Xiang YY, Wang S, Liu M, Hirota JA, Li J, et al. (2007) A GABAergic system in airway epithelium is essential for mucus overproduction in asthma. Nat Med 13: 862867. [Crossref]

10. Wang S, Xiang YY, Ellis R, Wattie J, Feng M, et al. (2011) Effects of furosemide on allergic asthmatic responses in mice. Clin Exp Allergy 41: 1456-1467. [Crossref]

11. Xiang YY, Chen X, Li J, Wang S, Faclier G, et al. (2013) Isoflurane regulates atypical type-A gamma-aminobutyric acid receptors in alveolar type II epithelial cells. Anesthesiology 118: 1065-1075. [Crossref]

12. Wang S, Xiang YY, Zhu J, Yi F, Li J, et al. (2017) Protective roles of hepatic GABA signaling in acute liver injury of rats. Am J Physiol Gastrointest Liver Physiol 312: G208-208G218. [Crossref]

13. Wang S, Sui S, Liu Z, Peng C, Liu J, et al. (2018) Protective roles of hepatic gammaaminobutyric acid signaling in acute ethanol exposure-induced liver injury. $J$ Appl Toxicol 38: 341-350. [Crossref]

14. Wang C, Kerckhofs K, Van de Casteele M, Smolders I, Pipeleers D, et al. (2006) Glucose inhibits GABA release by pancreatic beta-cells through an increase in GABA shunt activity. Am J Physiol Endocrinol Metab 290: E494-499. [Crossref]

15. Soltani N, Qiu H, Aleksic M, Glinka Y, Zhao F, et al. (2011) GABA exerts protective and regenerative effects on islet beta cells and reverses diabetes. Proc Natl Acad Sci U $S$ A 108: 11692-11697. [Crossref]

16. Xu E, Kumar M, Zhang Y, Ju W, Obata T, et al. (2006) Intra-islet insulin suppresses glucagon release via GABA-GABAA receptor system. Cell Metab 3: 47-58. [Crossref]

17. Best L (2005) Glucose-induced electrical activity in rat pancreatic beta-cells: dependence on intracellular chloride concentration. J Physiol 568: 137-144. [Crossref]

18. Davies SL, Roussa E, Le Rouzic P, Thévenod F, Alper SL, et al. (2004) Expression of $\mathrm{K}+-\mathrm{Cl}$ - cotransporters in the alpha-cells of rat endocrine pancreas. Biochim Biophys Acta 1667: 7-14. [Crossref]

19. Bansal P, Wang S, Liu S, Xiang YY, Lu WY, et al. (2011) GABA coordinates with insulin in regulating secretory function in pancreatic INS-1 $\hat{\mathrm{I}}^{2}$-cells. PLoS One 6 e26225. [Crossref]

20. Rorsman P, Berggren PO, Bokvist K, Ericson H, Mohler H, et al. (1989) Glucoseinhibition of glucagon secretion involves activation of GABAA-receptor chloride channels. Nature 341: 233-236. [Crossref]

21. Feng AL, Xiang YY, Gui L, Kaltsidis G, Feng Q, et al. (2017) Paracrine GABA and insulin regulate pancreatic alpha cell proliferation in a mouse model of type 1 diabetes. Diabetologia 60: 1033-1042. [Crossref]

22. Liu Z, Kim W, Chen Z, Shin YK, Carlson OD, et al. (2011) Insulin and glucagon regulate pancreatic $\hat{\mathrm{I}} \pm$-cell proliferation. PLoS One 6: e16096. [Crossref]

23. Balcazar N, Sathyamurthy A, Elghazi L, Gould A, Weiss A, et al. (2009) mTORC activation regulates beta-cell mass and proliferation by modulation of cyclin D2 synthesis and stability. J Biol Chem 284: 7832-7842. [Crossref]

24. Thorel F, Népote V, Avril I, Kohno K, Desgraz R, et al. (2010) Conversion of adult pancreatic alpha-cells to beta-cells after extreme beta-cell loss. Nature 464: 1149-1154 [Crossref]

25. Ben-Othman N, Vieira A, Courtney M, Record F, Gjernes E, et al. (2017) LongTerm GABA Administration Induces Alpha Cell-Mediated Beta-like Cell Neogenesis. Cell 168: 73-85. [Crossref]

Copyright: (C2018 Wei-Yang L. This is an open-access article distributed under the terms of the Creative Commons Attribution License, which permits unrestricted use, distribution, and reproduction in any medium, provided the original author and source are credited. 